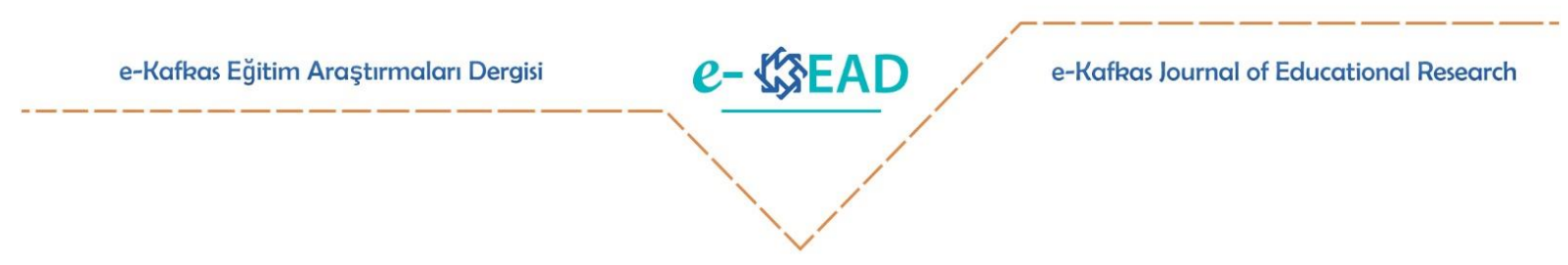

\title{
The Systematic Review of Studies about Web-Based Learning in Language Teaching Context ${ }^{1}$
}

\section{Zülal Ayar ${ }^{2}$}

\section{To cite this article:}

Ayar, Z. (2021). The systematic review of studies about web-based learning in language teaching context. e- Kafkas Eğitim Araştırmaları Dergisi, 8, 123-136. doi:10.30900/kafkasegt.957362

\section{Review article}

Received:25.06.2021

Accepted:19.08.2021

\begin{abstract}
As also labelled as online learning or e-learning, Web-based learning (WBL) has recently come to the forefront in language education thanks to a huge number of online teaching practices the pandemic has induced as well as the new platforms and some applications accommodating language studies. As such, the current research has been orchestrated to review prestigious academic papers on WBL in ELT published in flagship journals from the years 2015 to 2020. Moreover, it aims at clarifying the recent trends on e-learning platforms. 20 empirical studies which were based on quantitative, qualitative, or mixed designs and indexed in Clarivate Analytics (Thomson Reuters) were incorporated into the study. Having investigated them particularly considering the education context, participants, and the methods, the researcher discovered that an overwhelming majority of the studies were administered in higher education context according to mixed and quantitative research designs. Furthermore, the research on online learning platforms was heavily related to one of the macro skills (i.e. writing) besides listening and vocabulary to a degree. Another fundamental result was the limited number of studies employing blended learning contexts enriched with authentic activities which would make learners use higher-order thinking skills in the digital world. Finally, some suggestions have been offered to future studies on WBL in the light of the findings.
\end{abstract}

Keywords: E-learning, language learning, online learning, systematic review, web-based learning

\footnotetext{
${ }^{1}$ This paper was presented at the 2nd International Conference on Educational Research on 5th December 2020.

2 (iD) Zülal Ayar, Lecturer Doctor, ayarz@ankara.edu.tr, Ankara University, School of Foreign Languages, Turkey
} 


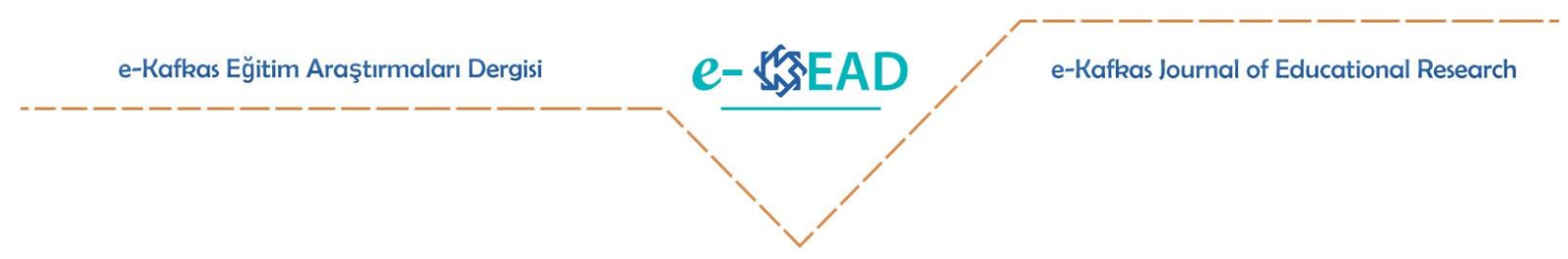

\title{
Dil Öğretimi Bağlamında Web Tabanlı Öğrenmeye Yönelik Çalışmaların Sistematik Olarak İncelenmesi ${ }^{1}$
}

\author{
Zülal Ayar ${ }^{2}$
}

Atıf:

Ayar, Z. (2021). Dil öğretimi bağlamında web tabanlı öğrenmeye yönelik çalışmaların sistematik olarak incelenmesi. e- Kafkas Eğitim Araştırmaları Dergisi, 8, 123-136. doi:10.30900/kafkasegt.957362

\section{Derleme Makalesi}

Geliş Tarihi:25.06.2021

Kabul Tarihi: 19.08 .2021

\section{$\ddot{O} \mathbf{z}$}

Çevrimiçi öğrenme, elektronik öğrenme ya da Web destekli öğretim olarak da söz edilen Web tabanlı öğrenme (WTÖ), pandeminin doğurduğu çok sayıda çevrimiçi öğretim uygulaması ve yeni platformlar sayesinde son zamanlarda dil öğrenimi ve öğretimi alanında oldukça ön plana çıkmıştır. Bu nedenle, mevcut araştırma, WTÖ üzerine 2015'ten 2020'ye kadar en saygın dergilerde yayınlanan akademik makaleleri incelemek için düzenlenmiştir. Ayrıca, bu analiz, elektronik öğrenme platformlarındaki son akımları ortaya çıkarmayı ve kapsama dâhil edilen çalışmaların bulgularını değerlendirmeyi amaçlamıştır. Buna göre, önceden saptanan belli başlı kriterler ışığında, Clarivate Analytics (Thomson Reuters)'te indekslenen nicel, nitel ya da karma desenle planlanan 20 araştırmanın çalışmanın içinde yer almasına karar verilmiştir. Araştırmacı, eğitim bağlamı, katılımcılar ve araştırma yöntemlerini dikkate alarak incelemelerini titizlikle tamamladıktan sonra, çalışmaların büyük bir çoğunluğunun karma ve nicel araştırma desenlerine göre yükseköğretim kurumunda yürütüldüğünü keşfetmiştir. Buna ek olarak, çevrimiçi öğrenme platformları üzerine yapılan araştırmaların bir dereceye kadar dinleme ve kelime dağarcığı gelişimini hedeflemelerine rağmen, aslında bir makro beceri olan yazma ile daha yakından ilgili oldukları saptanmıştır. Bir diğer önemli bulgu ise, öğrencilerin dijital dünyada üst düzey düşünme becerilerini kullanmalarını sağlayacak özgün etkinliklerle zenginleştirilmiş harmanlanmış öğrenme ortamlarının çalışmaların çoğunda eksik kalmış olmasıdır. Son olarak, WTÖ üzerine yapılacak gelecek araştırmalar için yaratıcılığı geliştirmek adına bazı öneriler sunulmuştur.

Anahtar Sözcükler: Çevrimiçi öğrenme, dijital öğrenme, dil öğrenimi, sistematik inceleme, web tabanlı öğrenme

\footnotetext{
${ }^{1} \mathrm{Bu}$ çalışma, Second International Conference on Educational Research isimli kongrede sözlü bildiri olarak sunulmuştur.

2 (D) Zülal Ayar, Öğr. Gör. Dr., ayarz@ankara.edu.tr, Ankara Üniversitesi, Yabancı Diller Yüksekokulu, Türkiye
} 


\section{Introduction}

Nowadays, language learners are accounted as digital natives and netizens by dint of the majority of student audience who are the members of Generation Z (Gen Z) or young adults born in the 2000s. Due to the fact that they are equipped with digital skills, and they can easily adjust to using digital technologies, web-based learning ('WBL' hereafter) platforms have appeared to be an indispensable part of language education. WBL can be portrayed as a pedagogy in which the content is conveyed via digital means and without a physically present teacher (Chung, 2003; Han, 2019). That is, WBL has to do with the lesson on the internet. The learners and teacher do not conduct face-to-face classes. Instead, the communication and coursework are managed through video conferencing, forums email, or chats. Therefore, interactive virtual learning systems are fairly ubiquitous in educational technology and (in) formal instructional settings.

From a broad perspective, technological innovations, such as unlimited Wi-Fi connections, online games, chatting, social networking, mobile learning (m-learning), blogging, and many other portable two-way communication tools have, in fact, reinforced the evolution of current learning approaches. Then, they have offered learners a range of online and in-person learning environments (Jeong, 2016; Miao \& Mao, 2018; Mudra, 2020; Prensky, 2001). The resources retrieved from virtual and e-learning platforms are hence quickly spreading the scope of language education outside the established learning contexts providing access to a set of digital contents, and strategies considering the pedagogical values (see Figure 1).

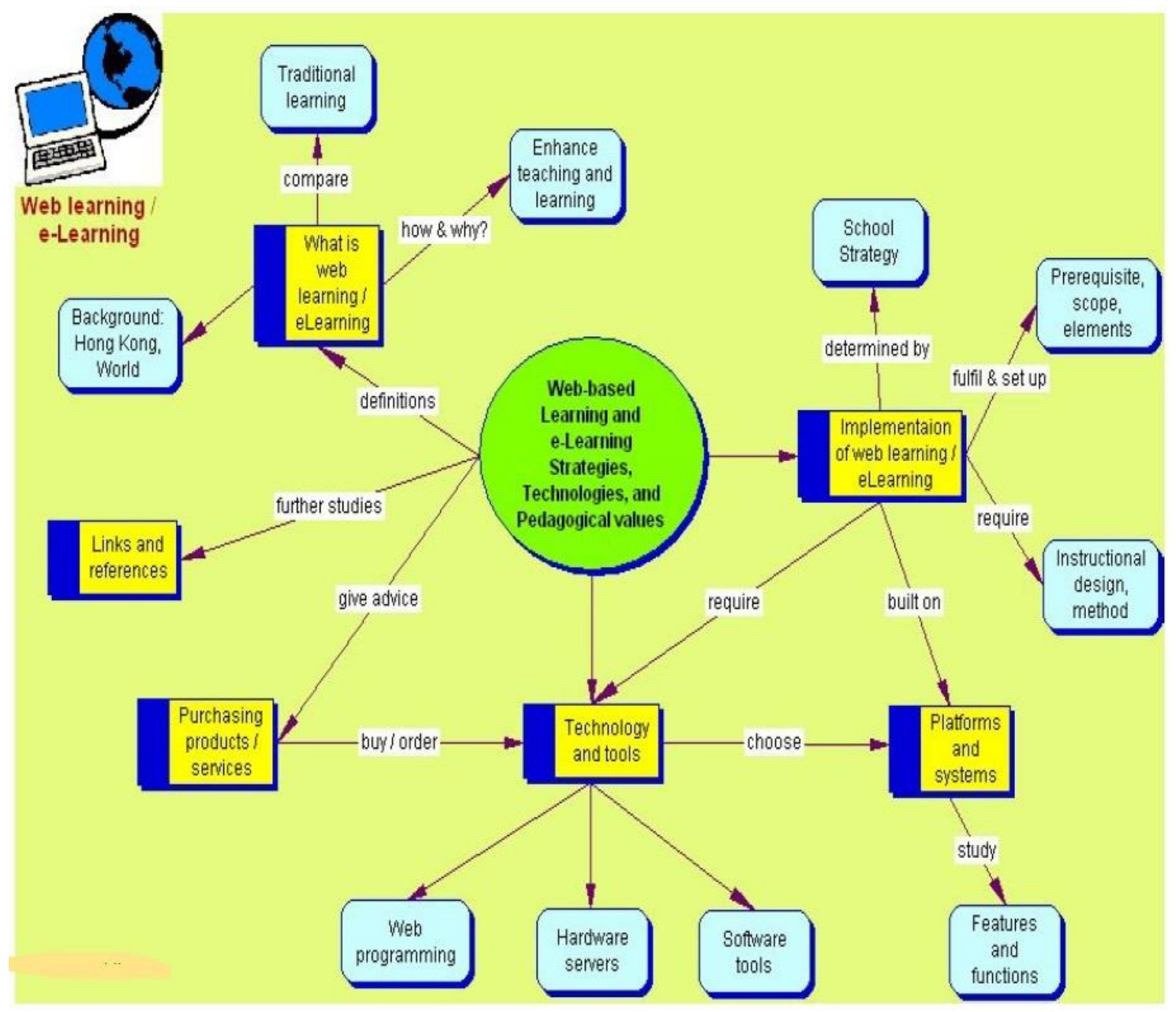

Figure 1. Web-Based Teaching and E-Learning (Chung, 2003, p.31.)

According to Figure 1, implementing online devices would facilitate experiential e-learning in consideration of student engagement, enthusiasm, language proficiency, and collaborative practices (Beard, Wilson, \& McCarter, 2007). In a similar vein, preferences, beliefs, attitudes, expectations, and 
(immediate) needs of learners must be widely-respected herein as well (Martin \& Ertzberger, 2013). Consequently, they will be able to steer their own learning in time through distance education and the timely assistance of teachers. As such, immediate feedback will yield reaching the learning outcomes, and it will also serve as a vehicle to achieve effective e-learning thoroughly employing 'electronic interactions' (Lee, 2002). This would entail unlimited access to the instructional contents in turn (Meurers, Kuthy, Nuxoll, Rudzewitz, \& Ziai, 2019).

All these facts imply that e-learning is to be characterized as a distinct setting from the traditional place-based classroom (on-campus) in terms of laying the weight on independent online studies and student-centred instruction as Figure 2 illustrates below.

\begin{tabular}{lll}
\hline Traditional Learning & & Web/E-Learning (using IT) \\
\hline - Teacher-centred instruction & - Student-centered instruction \\
- Single-sense stimulation & - Multisensory stimulation \\
- Single-path progression & - Multipath progression \\
- Single media & - Multimedia \\
- Isolated work & - Information exchange \\
- Information delivery & - Active/ exploratory/ inquiry- \\
- Passive learning & & based learning \\
- Factual, knowledge-based learning & Critical thinking and \\
- Isolated, artificial context & & informed decision-making \\
& & Authentic, real-world \\
& & context
\end{tabular}

Figure 2. The Differences between WBL and Traditional Learning (National Educational Technology Standards for Students, ISTE, 1998, p.2)

Figure 2 shows that WBL is advantageous over typical classroom instructions in the sense of providing efficient ways of how to deliver course materials, widening access to additional materials or serving as a source of supplementary materials on its own besides stimulating active learning. WBL has initially introduced hybrid and blended learning to the community of education, and then accelerated its impact on language teaching. To put it differently, the combination of the two can also be described as an approach that integrates face-to-face and distance learning to get the highest benefit from teachers, peers, and the content enriched with technological materials (Singh, 2003). Thus, hybrid or/and blended learning contains not only synchronous but also asynchronous learning activities. The former refers to e-courses, and a sense of community with real-time communication (e.g. online meetings, virtual lessons, instant messaging), whereas the latter implies non-periodic learning contexts supported with streaming media without forcing learners to respond or react just then, but allowing time to refine answers (e.g. recorded events). Accordingly, the learners respecting the great benefits of interaction must highly appreciate synchronous education, yet asynchronous lessons must be mostly opted by others who have the problem of autonomy/agency in the language learning process and look for easily accessible resources for mastery-based learning or independent studies (Cross, 2020). As is seen, the preferences and experiences of learners uncover how they can make a difference in personalized learning. Yet, it is to be remarked that these two types of education must be maintained in a delicate balance to arrange a creative and interactive learning atmosphere, critical thinking opportunities along with individualized mentoring.

As for the historical evolution of web-based environments in the education context, Ahamer (2010) straightforwardly expresses that online teaching and learning materials came out as the components of personal network or websites along with the spread and approval of the Internet almost at the beginning of the 90s. Besides the publications and uploads of language users, these materials were generally shared on the Net as supplemental materials by trading companies. The websites incorporating special themes started to accumulate links to the system in order to attract the target audience (i.e. the tutors) at the end of this century. In what follows, those notions were widened to the Learning Management System (LMS) in addition to the Learning Content Management System 
(LCMS) so that the educators could gain direct access to the online materials. Beyond that, as the resources involved authoring tools, it would allow online lessons, live lectures (video streaming), and teaching/learning materials to be published on the World Wide Web (WWW).

As a matter of fact, a tight bond subsists among WBL, web-based teaching and training based on didactic concepts and aims (Bork, 2001, Prensky, 2001). In parallel, computer-aided distance education, m-learning, internet-based training have been introduced within a variety of styles. However, although WBL activities have utilized these technological innovations and some learning models through online platforms, their general inclinations, contributions to language learners and student-centred instructions, and also the most favoured systems within several cases need to be illuminated via a systematic review (Ahamer, 2010). As a result, this study has been planned to increase concerns for WBL and lends credence to the researchers in that this issue must be prevalently addressed in language education in light of the following research questions:

1. What is the general inclination in WBL from the years 2015 till 2020 in terms of research method, educational context, and participants?

2. What are the most common web-based systems to teach the target language?

3. What are the recent trends in e-learning platforms in the last five years?

\section{Method}

Systematic reviews display a comprehensive look towards the literature. Thus, those studies are of utmost significance in the sense that they support revealing the obstacles in English Language Teaching (ELT). As such, referring to such kind of studies is much better for the conceptualization of language teaching and learning. The systematic review in the current paper adhered to a precise scheme examined research according to clearly identified principles and adopted an all-inclusive investigation approach (Gough, Oliver, \& Thomas, 2012; Meissner, 2021). To define and choose the journals to be included in the review, the following parameters were settled:

- The journals which explicitly focus on WBL or applications of e-learning platforms in ELT

- Fully-refereed journals in four quartiles (Q1, Q2, Q3 or Q4) indexed in Emerging Sources Citation Index (ESCI), Arts \& Humanities Citation Index (AHCI), or Social Sciences Citation Index (SSCI)

The reason why the ESCI, AHCI, and SSCI were determined as one of the parameters was that those journals are mostly known for their high research quality, and easier accessibility in academia (Zhang \& Leung, 2014). To identify these journals, the researcher also utilized another systematic stepwise process. She initially attempted to embrace database thesauri and preliminary work after determining the keywords and phrases. However, due to some technical problems, she applied to the Web of Science (WoS) Core Collection in Clarivate Analytics choosing "all databases" with multiple indexes. Using Boolean operators, she typed "web-based", "e-learning tool", "web-based platform", "online learning", and "web system" with various combinations of those terms as further syntheses, such as "web-based database applications" (e.g. "web* tools", "web* platform", "web* based platform") along with alternative words (e.g. "tool", "appliance", "instrument"). In consequence, education educational research, education scientific discipline, social sciences interdisciplinary, linguistics, instruments instrumentation, multidisciplinary science, and social issues were selected from the field categories. Moreover, she searched the studies refining results by publication years. Then, proceeding papers, reviews, book chapters, letter, postscriptums, editorial material, projects, and dissertations were excluded due to their inconvenience to the required document types. The last step was perusing esteemed journals manually and examining the references of distinguished articles not to miss out on any pertinent studies. As a consequence of this preliminary analysis, the researcher decided on fourteen journals meeting the parameters (see Table 1). All of those journals welcome studies in the field of language education or technology integrated language teaching, hence they are all within the scope of this research.

After selecting the journals, four criteria were adopted to identify studies. As Petticrew and Roberts (2006) stress, principled reviews necessitate researchers to formulate a strategic plan and 
determine the anteriority of how to single out the research. At that point, it is decisive to specify studies, discover relevant databases so as to retrieve the research and shape their data gathering system (Meissner, 2021). Therefore, after scrutinizing the relevant literature, the inclusion criteria for the current study were set. Accordingly, they must a) be written in English, b) incorporate empirical, rigorous research designs (qualitative, quantitative or both) to prove asserted claims or hypotheses and contribute to statistical analysis, c) have been published between January 2015 and October 2020, d) include online learning environments and assess the efficacy of WBL platforms adopted in distinct education contexts to illuminate common practices from modern language classes as well as English as a Foreign Language (EFL) and English as a Second Language (ESL) settings. Still, the studies using the web to advance teacher development, understand perceptions, beliefs or attitudes, and report teacher changes were not covered on the grounds that the review aimed at clarifying learning opportunities of students through e-learning tools and web-based applications.

In order to examine the chosen studies under the guidance of this systematic review, a review form was also designed by the researcher. Lots of formerly utilized forms in other systematic reviews were pointedly investigated while developing the form. This form would both comprise describing the demographic information concerning some essential characteristics of studies, such as participants, methods, education context, and qualitative information, such as general objectives, future suggestions. Afterwards, a number of experts in ELT scrutinized and assessed the review form for its reliability. The final version covered the following items:

- Information about the journal/publication year, main objectives, education context, methodology, the emphasis on WBL, general results and suggestions

Then, a colleague of the researcher screened these criteria and revised the studies based on the form. The approved research articles were set aside, yet five studies had been discussed owing to uncertainties about whether they must be accepted or excluded by the time consensus was reached. After this procedure, 20 articles were identified to be investigated.

After the reviews, the content analysis technique was employed seeing that this procedure would allow for inferences and interpretations about the research (Cohen \& Manion, 1994; Meissner, 2021). Then, independent qualitative data analysis started with the revision of confirmed articles in light of three foregoing research questions by the researcher and the expert. After two coders completed the coding and creation of groups based on the results of the studies, themes were established at the last stage of this process. Finally, a high inter-rater reliability level with .92 agreement was reported between the coders (Gwet, 2014).

\section{Findings and Discussion}

As stated above, the chosen research was analysed considering some study characteristics: participants, research methods, and education contexts. Apart from this, the recent issues within webbased language learning were analytically addressed through deductive reasoning. Firstly, the articles incorporated in this review must be plainly displayed.

Table 1.

Information about the Selected Studies

\begin{tabular}{llllll}
\hline $\begin{array}{l}\text { Assigned } \\
\text { Numbers for the } \\
\text { Articles }\end{array}$ & Journals & Year & $\begin{array}{l}\text { Research } \\
\text { Method }\end{array}$ & $\begin{array}{l}\text { Educatio } \\
\text { nal } \\
\text { context }\end{array}$ & Participants \\
\hline 1 & $\begin{array}{l}\text { International } \\
\text { Journal of } \\
\text { Knowledge and } \\
\text { Learning }\end{array}$ & 2016 & Mixed & College & EFL learners \\
& $\begin{array}{llll}\text { Journal of } \\
\text { Applied }\end{array}$ & 2016 & Quantitative & Higher & EFL learners \\
& Psycholinguistics & & & Education & \\
\hline
\end{tabular}


Table continued

\begin{tabular}{|c|c|c|c|c|c|}
\hline 3 & $\begin{array}{l}\text { Language } \\
\text { Learning \& } \\
\text { Technology }\end{array}$ & 2017 & Mixed & $\begin{array}{l}\text { Higher } \\
\text { education }\end{array}$ & $\begin{array}{l}\text { EFL and ESL } \\
\text { learners }\end{array}$ \\
\hline 4 & $\begin{array}{l}\text { International } \\
\text { Journal of } \\
\text { Emerging } \\
\text { Technologies in } \\
\text { Learning }\end{array}$ & 2017 & Quantitative & College & EFL learners \\
\hline 5 & $\begin{array}{l}\text { International } \\
\text { Journal of } \\
\text { Emerging } \\
\text { Technologies in } \\
\text { Learning }\end{array}$ & 2017 & Quantitative & College & EFL learners \\
\hline 6 & $\begin{array}{l}\text { Journal of } \\
\text { Computers in } \\
\text { Education }\end{array}$ & 2018 & Mixed & $\begin{array}{l}\text { Higher } \\
\text { education }\end{array}$ & EFL learners \\
\hline 7 & $\begin{array}{l}\text { International } \\
\text { Journal of } \\
\text { Emerging } \\
\text { Technologies in } \\
\text { Learning }\end{array}$ & 2018 & Quantitative & $\begin{array}{l}\text { Higher } \\
\text { Education }\end{array}$ & EFL learners \\
\hline 8 & $\begin{array}{l}\text { International } \\
\text { Journal of } \\
\text { Emerging } \\
\text { Technologies in } \\
\text { Learning }\end{array}$ & 2018 & Quantitative & $\begin{array}{l}\text { Higher } \\
\text { Education }\end{array}$ & EFL learners \\
\hline 9 & $\begin{array}{l}\text { International } \\
\text { Journal of } \\
\text { Information and } \\
\text { Communication } \\
\text { Technology } \\
\text { Education }\end{array}$ & 2018 & Quantitative & $\begin{array}{l}\text { Higher } \\
\text { Education }\end{array}$ & ESL learners \\
\hline 10 & $\begin{array}{l}\text { Turkish Online } \\
\text { Journal of } \\
\text { Distance } \\
\text { Education } \\
\end{array}$ & 2018 & Mixed & $\begin{array}{l}\text { Higher } \\
\text { Education }\end{array}$ & EFL learners \\
\hline 11 & $\begin{array}{l}\text { Argentinian } \\
\text { Journal of } \\
\text { Applied } \\
\text { Linguistics } \\
\end{array}$ & 2018 & Mixed & $\begin{array}{l}\text { Higher } \\
\text { Education }\end{array}$ & EFL learners \\
\hline 12 & $\begin{array}{l}\text { International } \\
\text { Journal of } \\
\text { Distance } \\
\text { Education } \\
\text { Technologies } \\
\end{array}$ & 2019 & Quantitative & $\begin{array}{l}\text { Higher } \\
\text { Education }\end{array}$ & EFL learners \\
\hline 13 & $\begin{array}{l}\text { Computer } \\
\text { Assisted } \\
\text { Language } \\
\text { Learning }\end{array}$ & 2019 & Qualitative & High School & EFL learners \\
\hline 14 & $\begin{array}{l}\text { Journal of } \\
\text { Computing in } \\
\text { Higher Education }\end{array}$ & 2019 & Mixed & $\begin{array}{l}\text { Higher } \\
\text { Education }\end{array}$ & EFL learners \\
\hline 15 & $\begin{array}{l}\text { Education and } \\
\text { Information } \\
\text { Technologies }\end{array}$ & 2019 & Mixed & $\begin{array}{l}\text { Elementary } \\
\text { School }\end{array}$ & EFL learners \\
\hline
\end{tabular}


Table continued

\begin{tabular}{|c|c|c|c|c|c|}
\hline 16 & $\begin{array}{l}\text { International } \\
\text { Journal of } \\
\text { Emerging } \\
\text { Technologies in } \\
\text { Learning }\end{array}$ & 2019 & Quantitative & College & EFL learners \\
\hline 17 & $\begin{array}{l}\text { International } \\
\text { Journal of } \\
\text { Emerging } \\
\text { Technologies in } \\
\text { Learning }\end{array}$ & 2019 & Quantitative & $\begin{array}{l}\text { Students } \\
\text { from } \\
\text { different } \\
\text { levels of } \\
\text { education }\end{array}$ & EFL learners \\
\hline 18 & $\begin{array}{l}\text { International } \\
\text { Journal of } \\
\text { Emerging } \\
\text { Technologies in } \\
\text { Learning }\end{array}$ & 2019 & Qualitative & $\begin{array}{l}\text { Higher } \\
\text { Education }\end{array}$ & EFL learners \\
\hline 19 & $\begin{array}{l}\text { The Qualitative } \\
\text { Report }\end{array}$ & 2019 & Qualitative & $\begin{array}{l}\text { Higher } \\
\text { Education }\end{array}$ & EFL learners \\
\hline 20 & $\begin{array}{l}\text { Annual Review of } \\
\text { Applied } \\
\text { Linguistics }\end{array}$ & 2019 & Quantitative & $\begin{array}{l}\text { Secondary } \\
\text { School }\end{array}$ & EFL learners \\
\hline
\end{tabular}

Table 1 presents the literature search with the articles, journals, publication dates according to respective study variables, namely research orientations, education context, the sample in research. Two studies operated in 2016 and another three conducted in 2017 can be easily discerned in the table above. It is followed by six academic work carried out in higher education in the 2018 academic year. Finally, the other nine articles from the year 2019 appear in the list, which takes this date to the top thanks to the highest number of research recorded in this time span. Still, neither in 2015 nor in 2020 was any empirical research involved in the review due to not fulfilling the inclusion criteria. Respecting another significant point, that is the journals, the reviewer noted seven studies from the 'International Journal of Emerging Technologies in Learning', whereas all of the other journals were included in this study with solely one publication.

Concerning the research methods, ten quantitative, three qualitative and seven mixed designs were adopted to analyse the data. Furthermore, a majority of the experiments were mostly administered at the tertiary level taking account of the colleges $(\mathrm{N}=4)$ and higher education context $(\mathrm{N}=12)$. Nevertheless, only one research was implemented in high school, elementary school, and secondary school for each. The other study covered in this review had a unique category in that students in the sampling were from different levels of education. This resulted in the alarming signals of narrowing down the scope of studies only to universities, which is the final phase of education. Yet, what learners experience up until this point seems to have been disregarded. Younger learners' digital literacy and their exploitations of internet-based tasks could have thrived in the mainstream in language studies at least considering the recent research (Cross, 2020; Moorhouse \& Beaumon, 2020; Mudra, 2020). The findings also exposed that ESL learners partook merely in one design, similarly only one study focused on both EFL and ESL learners throughout the investigation. The others particularly concentrated on EFL learners $(\mathrm{N}=18)$ to inform us about their online learning experiences. This would also unveil the excessive deficits of examining ESL students' access to e-learning platforms and comparisons of two contexts to determine any possible motives behind the success or failures and orient future studies accordingly.

As for the frequently adopted web-based systems to teach English, a wide range of online platforms were discovered to be utilized in these studies: Ted, Research Writing Tutor (RWT), the Browser/Server $(\mathrm{B} / \mathrm{S})$ architecture, WALLeT project, English Language Skills Training System (ELSTS), Jukuu within computer-distance education, gamified environments, such as Kahoot, Quizlet, besides Powtoon (video maker), Nearpod (distance-hybrid learning setting) as well as YouTube as content sharing and organizing systems, "WritingGen" blog, Sketch Engine for Language Learning (SkELL), DynED (English language learning software), Model-View-Controller (MVC) architectural 
pattern, Massive Open Online Course (MOOC) and Google Collaboration, the ADO.NET based on B/S structure, LMS covering Blackboard, Moodle, Canvas, Desire2learn, Sakai, and FeedBook. Additionally, Facebook was referred to as social media platform and adapted in two studies. As it would not be feasible to identify the frequently held e-learning system(s) specifying each paper one by one, they were characterized in terms of whether to be constructed according to blended learning. As a result, the articles numbered 5, 6, 10,11, 14, 15, 16, and 19 in Table 1 were found to refer to blended learning in their designs. The 8th study was classified in Moodle platform due to using a computer modular learning environment. 11th and 19th research respected both Moodle and blended learning programs, whereas the others seemed to prefer developing new tools $(\mathrm{N}=3)$ or directly adopting any other existing web-based systems $(\mathrm{N}=8)$. Therefore, it can be firmly claimed that blended activities using current online platforms were favoured by scholars in data gathering and analysis. Nonetheless, it was quite surprising that none of the research in this review applied to any of the popular social networks, such as LinkedIn, MySpace, Pinterest, Twitter, Instagram, WhatsApp Messenger or other popular E-Systems as Edmodo, Google forms, Padlet, Socrative, ClassTree, Class Dojo, Wunderlist, Evernote, SeeSaw, to name but a few. It was despite their profitability in terms of being free, productive, secure applications with their intuitive features, and almost endless storage besides offering fun while gauging student understanding in real-time.

Regarding the common issues that researchers discussed resorting to e-learning and teaching tools in the last five years, the trends in designs were grouped under four broad themes even though they were intertwined with one another to some extents.

\section{Writing Skill and WBL Tools}

Though cultivating comprehensive language ability was heavily underlined in the studies, writing improvement was by far the most examined aspect out of all skills. Cotos, Link and Huffman (2017) probed into if and how using direct corpus with the contributions of a web-based system (i.e. RWT) could change student writers' genre learning along with the advance in general writing skill. In the end, they noted the rise of awareness and the recovery of the target genre among writers and presented recommendations to deepen cognitive development through data-driven learning. Lu, Zheng and $\mathrm{Li}$ (2018) examined the impact of embedded summary writing on speaking related anxiety in a computer-based testing environment with the design of four modules on ELSTS. They revealed learners' understanding of the positive effect of summary writing on cognition and the process of language in mind besides the ebb in speaking anxiety. The result signifies strong bonds and interaction of two productive skills in foreign language anxiety.

Unlike any other researchers, $\mathrm{Li}$ and Zhang (2018) drew attention to flipped classroom instruction based on the online video while teaching practical English writing. Subsequently, they dwelled on the success of resorting to the flipped classroom in practical English writing via Jukuu Pigai.org. Considering this point from a different angle, Selçuk, Jones and Vonkova (2019) searched whether and how the social network (i.e. Facebook) could foster a collaborative writing process among EFL learners through self-reported accounts. Then, peer leadership was referred to be the great white hope thanks to its impact on self-efficacy, and self-regulation in language learning particularly to further writing practices. Similarly, Gava and Costa (2018) aimed to explore improvements in writing embracing collaborative online discussion forum within the frame of socio-cognitive perspective. They found out that social and cognitive practices reinforced with information and communication technology accelerated constructing general language knowledge cooperatively. In general, studies under this theme discovered the close liaisons of writing with the cognitive abilities of learners as will be discussed individually later and the leverage of written communication on soft skills.

\section{Attitudes towards WBL Platforms}

The study of $\mathrm{Yu}$ (2018) took the issue to another critical concept associated with virtual language teaching and learning system: the attitudes of learners toward studying English. He looked into the approaches of learners about completing an English course on Facebook. After the study, they were found to be less motivated to interact with peers and take language lessons adopting WBL platforms when compared with face-to-face education. In that vein, Quadir, Chen and Yang (2019) 
checked learners' attitude and perceptions of blog writing using the "WritingGen" blog. Accordingly, digital native writers were pleased with the blog writing exercise about higher uptakes and their frequent uses. Correspondingly, studies scrutinizing the needs of online English language learning, assessment of the efficacy of a model considering learner success and beliefs appeared in the research of Alizadeh (2019), İnal and Korkmaz (2019), and Qiu (2019) as underscored by Martin and Ertzberger (2013) and Singh (2003). Similar to Beard, Wilson, and McCarter (2007), Hirata and Hirata (2019) also respected psychological characteristics of language learning investigating learners' assessment of online corpora (i.e. SkELL) in English classes to report their attitudes and motivation. Overall, the common ground these scholars met was the close relationship amongst the efficiency of web resources, attitudes towards learning English and employing those tools respecting the vantage point of learners on this issue, which overlaps with Mudra (2020), and Prensky (2001).

\section{Improvement of Listening and Vocabulary Using Digital Learning Systems}

Improving listening and expanding vocabulary drastically were highlighted as well in these studies. Miao and Mao (2018) analysed the positive influences of computer modular learning on pre-, in-, and post-listening phases. Karaaslan, Kılıç, Güven-Yalçın and Güllü (2018) reflected the progress of learners in vocabulary learning via digital tools and games, such as Kahoot and Quizlet along with exploring the impacts of synchronous and asynchronous online education on the overall learning experience. Last of all, researchers elaborated peer facilitation and collaboration through online forums and materials to promote learning and autonomy as was partially mentioned in former paragraphs. Jeong (2016) emphasized developing the communicative competence of learners with authentic materials and interactive activities from the TED platform. In doing so, he also aimed at disclosing their perceptions and stressed the weight of flipped instruction in language classes similar to Li and Zhang (2018). By the same token, Liang and Pang (2019) worked on teaching mode innovations so as to inspire learners to participate in lessons and cooperate, arise interest in language studies besides gaining new insights into foreign language learning. Han (2019) reinforced this view with a conceptual model based on an autonomous learning system and also declared to have designed it to compensate for the lack of collaborative communication in traditional classes. He concluded with the promising future of using object-oriented technology to entail accuracy and implied the significance of revealing needs to lead us to the creation of functional models to foster language education and provide an autonomous learning environment. Despite employing the same model with Han, Chai (2017) conceived, administered, and then tested B/S architecture only by taking the learning needs into account. In the end, she proved its feasibility and efficiency as a self-learning platform and a student-oriented development technology. On the whole, the research in this section resolved the enhancement of learner success and engagement thanks to the positive correlation of listening instructions and the word learning process.

\section{Cognitive Skills and E-learning Platforms}

Lu (2017) studied learner cognition by revisiting constructivism, cognitive-interactionism along sociocultural perspectives in psychology and the distillation of schematic knowledge. He used a web-based hybrid learning model to check learners' memory skills with 1000 words and 24 units as well as aiming to see its power during the memorization process. Both the level of motivation and their achievement rates were found to increase in the end as in the research of Beard, Wilson, and McCarter (2007). Furthermore, gaining independence and developing new learning habits were regarded as investments in future learning. Likewise, Zahonero and Degano (2016) noted the headway in metalinguistic awareness of learners via wiki-assisted language learning and translation as a collaborative computer-assisted specialised program. Finally, Meurers et al. (2019) developed a webbased FeedBook to replace printed books providing immediate scaffolded feedback to exercises and randomized controlled field trials; then they concluded with its effectiveness on English language learners.

Taken together, the general themes established from the studies on virtual language learning platforms can be outlined as cognitive skills, writing skill competency, development of vocabulary as a sub-skill of macro skills and listening through interactive digital tools, and an essential element of psychological factors, the attitudes or manners of learners towards WBL. Regarding the inclinations 
these reviewed articles are suggesting in addition to the future line of research that seems ahead, the implementation of blended learning, blog-writing, gamification, peer leadership approach, information and communication technologies as well as different computer-mediated communication would be promising in formulating knowledge and higher-order thinking skills besides enhancing students' academic achievement and learning enthusiasm in this digital age.

\section{Conclusion and Implications for Future Research}

The study has intended to expose general dispositions in WBL from 2015 to 2020 analysing the modus operandi, education context, and participating groups. According to the results, the best part of these studies has been handled in higher education on EFL learners using quantitative designs and blended activities on the web in 2019. As the current review has also aimed to divulge hotly-debated points, and cutting-edge research focus on digital platforms, some suggestions for new venues of research and implications regarding e-learning are listed below in parallel with the analysis.

In light of the findings of this systematic review, studies about online learning platforms are detected to be heavily related to one macro skill (writing) besides listening and vocabulary to a degree, but marginalized the other basic skills instead of harmonizing all thoroughly abiding by integrated skills approach. But for this problem, it would pave the way for making learners associate four skills, and build their strategies to overcome learning difficulties. This analysis also affirms that using webbased multimedia in language education requires teachers to consider the opportunities they provide to learners primarily in terms of collaboration and interaction through social networks. To put it differently, implementing information and communication technologies to make learners use higherorder thinking skills in the digital world as in discussion forums or learning communities has been underlined with due diligence. To do it, the needs of learners must be well-clarified; in addition to that their views regarding the application of identified tools and attitudes towards the efficacy of digital systems or materials on language learning continuum ought to be recognized beforehand. In doing so, blended learning contexts enriched with authentic activities will raise awareness of being an independent language user through personalized learning, and inform learners of ubiquitous networked technologies besides allowing for strengthening cognitive language functions.

Furthermore, it has been explored that a close liaison subsists between the cognitive abilities of learners and their writing skill. Therefore, leveraging effective written communication on soft skills attaches high importance to help raise attainments in language studies. Additionally, a strong affinity exists among learner attitudes, the efficacy of web resources, and adopting e-tools according to their opinions and preferences. Finally, the research in this review highlights that learners' success and motivation will boost provided that the vocabulary learning process and listening instructions in WBL systems have been well-correlated with one another.

As for the suggestions for further studies, there is a growing necessity for executing WBL research, especially on young learners by directly addressing digital literacy skills to denote influences on their success and interaction. Moreover, more research examining ESL students' access to elearning platforms is in need in the field. This stance accentuates the fact that learners need to get accustomed to online experiences and virtual lessons in a truly flexible-learning environment, have control of the pacing of their learning for self-governance and gaining a sense of themselves as an individual language learner. Hence, apart from very well-known systems, some different settings, such as massive collection of forums (e.g. Reddit), e-classes (e.g. Schoology, HyperDocs, Edmodo), video conferencing tools (e.g. PB Works, Blendspace, Zoom) as well as Digg or RSS readers as online reading resources, workspaces (e.g. Slideshare, LiveBinders and Dropbox), social media (e.g. Twitter, Instagram, Pinterest, WhatsApp, LinkedIn, MySpace, Messenger), infographics in addition platforms organizing and sharing the content can be operated to enhance versatile virtual communication, increase both learner enthusiasm in language education, and the efficiency of study skills in a broad sense. Further, using digital games which fulfil a vital complementary role in language learning as Karaaslan et al. (2018) and Han (2019) feature would catalyse learning. In the same vein, hinging upon the 'here and now mobile learning' principle, the gamified environments might be adopted more as authentic materials and research instruments to search whether learners get fully involved in informal collaborative learning tasks in extended contexts (Martin \& Ertzberger, 2013). 
Similarly, Web-Based Simulation (WBS) would enable learners to gain hands-on experience, embolden them to be engaged in different real-like scenarios. Besides enhancing interaction via robust projects, WBSs will boost the personalization of language learning. This is also compatible with the view of hybrid classes by virtue of combining brick-and-mortar school and digital classroom. Nevertheless, merely Han's (2019) study has allowed for analysing live online learning with simulations, which alone calls forth the niche in the literature to be fulfilled in further research. Moreover, studies incorporating the reading skill into research design and methodology are quite rare in mobile technology and digital learning contexts, and hence future empirical research should tease out relevant reading activities.

Finally, based on the greatest disappointment of the result in that no studies from the year 2020 have been among the identified articles, new research conducted right after the outbreak of the Covid-19 crisis seems to be appreciated in the field. They must be conducted to indicate the impact of the pandemic on language education, precipitate learning opportunities within adaptive hypermedia, offer e-learning related pedagogical content knowledge (see, for example, Rapanta, Botturi, Goodyear, Guàrdia, \& Koole, 2020), and also reveal its potential drawbacks or challenges in different contexts. Then, WBL platforms will be the agent of change in a vast array of different language features to be executed in studies of late.

\section{Ethics Statement}

In this study, as the author, I declare that the rules stated in the "Higher Education Institutions Scientific Research and Publication Ethics Directive" are complied with and that I do not take any of the actions based on "Actions against Scientific Research and Publication Ethics". At the same time, I declare that there is no conflict of interest, that the author contributes to the study, and that all the responsibility belongs to the article author in case of all ethical violations.

\section{Copyrights}

The works published in e-Kafkas Journal of Educational Research are licensed under a Creative Commons Attribution-NonCommercial- 4.0 International License. 


\section{References}

Ahamer, G. (2010). A short history of web based learning including GIS. International Journal of Computer Science \& Emerging Technologies, 1(4), 101-111.

Alizadeh, I. (2019). Using an LMS in teaching English: A qualitative content analysis of medical sciences students' evaluations and suggestions. The Qualitative Report, 24(11), 2851-2873. Retrieved from https://nsuworks.nova.edu/tqr/vol24/iss11/12

Beard, C., Wilson, J. P., \& McCarter, R. (2007). Towards a theory of e-learning: Experiential elearning. Journal of Hospitality, Leisure, Sport and Tourism Education, 6(2), 3-15. Retrieved from: www.heacademy.ac.uk/hlst/resources/johlste

Bork, A. (2001). Adult education, lifelong learning, and the future. Campus-Wide Information Systems, 18(5), 195-203.

Chai, J. (2017). Development of computer English education platform based on B/S model. International Journal of Emerging Technologies in Learning, 12, 86-94. doi:10.3991/ijet.v12.i08.7134

Chung, T. (2003). Web-based learning (E-learning). Retrieved from http://www.thecorner.org/elearning.

Cohen, L., \& Manion, L. (1994). Research methods in education (4th Ed.). New York, NY: Routledge.

Cotos, E., Link, S., \& Huffman, S. (2017). Effects of DDL technology on genre learning. Language Learning \& Technology, 21(3), 104-130. Retrieved from http://lit.msu.edu/issues/october2017/cotoslinkhuffman.pdf

Cross, R. (2020). Synchronous online teaching of English as a foreign language with young learners: How do teachers do it? CSBS INSPIRE Student Research \& Engagement Conference. 79. https://scholarworks.uni.edu/csbsresearchconf/2020/all/79

Gava, I. Y., \& Costa, N. V. D. (2018). A socio-cognitive approach to the development of EFL writing skills through a collaborative online discussion forum in a university course. Argentinian Journal of Applied Linguistics, 6(2), 6-25.

Gough, D., Oliver, S. \& Thomas, J. (2012). An introduction to systematic review. London: Sage Publications.

Gwet, K. L. (2014). Handbook of inter-rater reliability: The definitive guide to measuring the extent of agreement among raters. Gaithersburg MD: Advanced Analytics.

Han, H. (2019). Design and implementation of web-based English autonomous learning system. International Journal of Emerging Technologies in Learning, 14, 18-26. doi:10.3991/ijet.v14i06.9718

Hirata, Y. \& Hirata, Y. (2019). Applying 'Sketch Engine for Language Learning' in the Japanese English classroom. Journal of Computing in Higher Education, 31, 233-248. doi:10.1007/s12528-019-09208-z

İnal, M. \& Korkmaz, Ö. (2019). The effect of web based blended learning on students' academic achievement and attitudes towards English course. Education and Information Technologies, 24, 2603-2619. doi:10.1007/s10639-019-09890-7

Jeong, K. (2016). Integrating a web-based platform to promote creativity and authenticity in language classrooms. International Journal of Knowledge and Learning, 11, 127-136. doi:10.1504/IJKL.2016.079752

Karaaslan, H., Kılıç, N., Güven-Yalçın, G., \& Güllü, A. (2018). Students' reflections on vocabulary learning through synchronous and asynchronous games and activities. Turkish Online Journal of Distance Education, 19(3), 53-70.

Lee, L. (2002). Enhancing learners' communication skills through synchronous electronic interaction and task-based instruction. Foreign Language Annals, 35(1), 16-24.

Liang, X. \& Pang, J. (2019). An innovative English teaching mode based on massive open online course and Google collaboration platform. International Journal of Emerging Technologies in Learning, 14, 182-192. doi:10.3991/ijet.v14i15.11148 
Liu, X. \& Zhang, J. (2018). Application of computer distance education in practical English writing teaching. International Journal of Emerging Technologies in Learning, 13, 71-82. doi:10.3991/ijet.v13i04.8471

Lu, L. (2017). Study on the effectiveness of computer-aided software in helping college students memorize English words. International Journal of Emerging Technologies in Learning, 12, 118-127. doi:10.3991/ijet.v12.i08.7146

Lu, Z., Zheng, C. \& Li, Z. (2018). Effects of embedded summary writing on EFL learners' anxiety and oral production in a computer-based testing environment. Journal of Computers in Education, 5, 221-241. doi:10.1007/s40692-018-0105-1.

Martin, F., \& Ertzberger, J. (2013). Here and now mobile learning: An experimental study on the use of mobile technology. Computers and Education, 68, 76-85.

Meissner, C. A. (2021). "What works?" Systematic reviews and meta-analyses of the investigative interviewing research literature. Applied Cognitive Psychology, 35, 322-328. doi: $10.1002 /$ acp. 3808

Meurers, D., Kuthy, K. D., Nuxoll, F., Rudzewitz, B., \& Ziai, R. (2019). Scaling up intervention studies to investigate real-life foreign language learning in school. Annual Review of Applied Linguistics 39, 161-188. doi:10.1017/S0267190519000126

Miao, J. \& Mao, L. (2018). Influence analysis of computer modular learning environment on college English listening teaching effect. International Journal of Emerging Technologies in Learning, 13, 129-138. doi:10.3991/ijet.v13i04.8476

Moorhouse, B. L., \& Beaumont, A. M. (2020). Utilizing video conferencing software to teach young language learners in Hong Kong during the COVID-19 class suspensions. TESOL Journal, 11, 545. doi:10.1002/tesj.545

Mudra, H. (2020). Digital literacy among young learners: How do EFL teachers and learners view its benefits and barriers? Teaching English with Technology, 20(3), 3-24, http://www.tewtjournal.org

National Educational Technology Standards for Students. (1998). ISTE.

Petticrew, M. \& Roberts, H. (2006). Systematic reviews in the social sciences: A practical guide. Malden: Blackwell Publishing.

Prensky, M. (2001). Digital game-based learning. New York: McGraw-Hill.

Qiu, L. (2019). Computer-aided English teaching platform based on secure shell framework. International Journal of Emerging Technologies in Learning, 14, 143-154. doi:10.3991/ijet.v14i16.11149

Quadir, B., Chen, N. S., \& Yang, J. C. (2019). Investigation of the generational differences of two types of blog writers: The generation gap influence. International Journal of Distance Education Technologies, 17, 54-70. doi:10.4018/IJDET.2019100104

Rapanta, C., Botturi, L., Goodyear, P., Guàrdia, L., \& Koole, M. (2020). Online university teaching during and after the Covid-19 crisis: Refocusing teacher presence and learning activity. Postdigital Science and Education, 2, 923-945. doi:10.1007/s42438-020-00155-y

Selçuk, H., Jones, J., \& Vonkova, H. (2019). The emergence and influence of group leaders in webbased collaborative writing: Self-reported accounts of EFL learners. Computer Assisted Language Learning. doi:10.1080/09588221.2019.1650781

Singh, H. (2003). Building effective blended learning programs. Educational Technology, 43(6), 5154.

Yu, W. C. W. (2018). English writing via a social networking platform. International Journal of Information and Communication Technology Education, 14, 17-32. doi: 10.4018/IJICTE.2018010102

Zahonero, M. L. \& Degano, C. (2016). Enhancing metalinguistic awareness through collaborative computer assisted specialised translation: A rationale for the WALLeT project. Journal of Applied Psycholinguistics, 14(1), 9-30.

Zhang, Y., \& Leung, L. (2014). A review of social networking service (SNS) research in communication journals from 2006 to 2011. New media \& society, 17, 1007-1024. doi: $10.1177 / 1461444813520477$ 